Mavi Atlas, 5(2)/2017: 383-401. Araştırma Makalesi | Research Article

Makale Geliş | Received: 01.08.2017

Makale Kabul | Accepted: 04.10.2017

DOI: $10.18795 /$ gumusmaviatlas. 351484

Ayhan DEVER

Yrd. Doç. Dr. | Assist. Prof. Dr. Ordu Üniversitesi, Beden Eğitimi ve Spor Yüksekokulu, Ordu-Türkiye Ordu University, School of Physical Education and Sports, Ordu-Turkey orcid.org/0000-0002-8300-5290 ayhandever@odu.edu.tr

Mehmet KOCA

Yrd. Doç. Dr. | Assist. Prof. Dr. Ordu Üniversitesi, Fen-Edebiyat Fakültesi, Sosyoloji Bölümü, Ordu-Türkiye Ordu University, Faculty of Arts and Sciences, Department of Sociology, Ordu-Turkey

e_mehmetkoca@hotmail.com

\title{
Beden Eğitimi ve Spor Yüksekokulu Öğrencilerinin Sosyal Medya Kullanımına Yönelik Düzeylerinin Değerlendirilmesi: Ordu Üniversitesi Örneği
}

Öz

Bu çalışmanın amacı Ordu Üniversitesi Beden Eğitimi ve Spor Yüksekokulu öğrencilerinin sosyal medya kullanımlarına yönelik düzeylerinin belirli değişkenler etrafında ölçülmesidir. Bu düşünce içerisinde Ordu Üniversitesi Beden Eğitimi ve Spor Yüksekokulu öğrencilerinden rasgele örnekleme yöntemi kullanılarak 206 öğrenci belirlenmiştir. Öğrencilere sosyo - demografik bilgileri içeren ve sonrasında da Sosyal Medya Kullanımına Yönelik Tutum Ölçeği'nin yer aldığı anket uygulanmıştır. Ölçek 35 maddeden oluşan 5'li likert tipi ölçektir. Veriler ilişkisiz örneklemler için T testi ve tek yönlü varyans analizi (ANOVA) ile değerlendirilmiştir.

Anahtar Kelimeler: Sosyal Medya Kullanımına Yönelik Tutum Ölçeği, Sosyal Medya, Instagram, Facebook, Twitter.

\section{An Evaluation of Physical Education and Sports School Students' Social Media Use: An Example from Ordu University}

\begin{abstract}
The aim of this study is to measure the level of social media use of Ordu University Physical Education and Sports School students according to various variables. 206 students were randomly selected from Ordu University Physical Education and Sports School. Students completed a questionnaire including socio-demographic informations and a Scale of Attitude towards Social Media Use. This scale is a 5-point Likert-type scale consisting of 35 items. T-test for independent samples and One - Way Anova test were performed to evaluate the datas.
\end{abstract}

Keywords: Scale of Attitude Towards Social Media Use, Social Media, Instagram, Facebook, Twitter. 
Ayhan DEVER ve Mehmet KOCA, “Beden Eğitimi ve Spor Yüksek Okulu Öğrencilerinin Sosyal Medya Kullanımına Yönelik Düzeylerinin Değerlendirilmesi: Ordu Üniversitesi Örneği”, Mavi Atlas, 5(2)/2017: 383-401.

\section{Giriş:}

Küreselleşme süreci ile birlikte günümüz modern dünyası küçük bir köy haline gelmiştir. Bunun temelinde ise teknolojinin payı asla yadsınamayacak bir boyuttadır. Özellikle günümüzde teknolojinin son harikası olan internet, bireyleri peşinden sürükleyen bir unsur haline gelmiştir. Dünya genelinde insanların büyük bir kısmı interneti hemen her gün kullanmakta ve özellikle sosyal medya platformlarına yoğun bir ilgi göstermektedir.

Sosyal medya platformları özellikle 2000'li yılların başından itibaren hayatımıza girmiş ve hayatımızı adeta çepeçevre sarmıştır. Bireyler kendilerini sosyal medya platformlarında daha rahat ifade etmiş, farklı düşüncelerini paylaşmış ve adeta bireyin, sanal dünyadaki kendi karşılığı haline gelmiştir. Böylece bireyler, adeta sosyal medya platformlarına bağımlı hale gelerek, kendi sanal gerçekliklerini sürdürmeye devam etmiş ve devam etmektedirler.

\section{Internet ve Sosyal Medya:}

Oskay (2005: 9)'a göre iletişim, “belirli bir coğrafya parçasında aynı doğa koşulları içinde varlıklarını sürdürmek için araç ve gereçler bulan, bu konuda çeşitli bilgiler üretmiş bulunan, bunları belirli işbölümü yöntemlerine göre kullanan, kendi aralarındaki bu iş bölümünden kaynaklanan farklılaşmaları haklılaştırmak için çeşitli değerler ve inançlar üreterek toplumun farklı kesimlerini ortak üst kimlikler içinde kaynaştırmayı amaçlayan insanların etkinliğidir”. Son yıllarda bilgisayarların gelişmesi ve bu bilgisayarlara bağlı olarak internet kullanımının yaygınlaşması iletişim etkinliklerinde değişimler meydana getirmiştir. $\mathrm{Bu}$ değişim de geleneksel iletişim modellerinin terk edilerek yeni iletişim modellerine geçilmesiyle sonuçlanmıştır. Diğer bir deyişle iletişimin ve bu iletişimden doğan etkileşimin yönü ve şekli değişmiştir.

Günümüzde bu yön ve şekil değişikliğine olumlu bakanlar olabildiği gibi olumsuz bakanlarda bulunmakta, böylece internetin etkilerini konu edinen görüşler iki farklı grup altında toplanabilmektedir. Birinci görüş; çevrimiçi (online) dünyanın, var 
Ayhan DEVER ve Mehmet KOCA, "Beden Eğitimi ve Spor Yüksek Okulu Öğrencilerinin Sosyal Medya Kullanımına Yönelik Düzeylerinin Değerlendirilmesi: Ordu Üniversitesi Örneği”, Mavi Atlas, 5(2)/2017: 383-401.

olan yüz yüze etkileşimleri güçlendirdiğini yada desteklediğini ileri sürerek elektronik ilişkileri desteklemektedir. Örneğin yurt dışında bulunan birisi, arkadaşları ve evdeki akrabalarıyla düzenli olarak iletişim kurmak için interneti kullanabilmekte, mesafe ve ayrılıktan doğan sorunları daha aza indirebilmektedir. Diğer yandan internet, sosyal ağlarda ve sohbet odalarında tanışan anonim çevrimiçi kullanıcıların ilgili oldukları ortak konuları tartışmalarına zemin hazırlamak gibi yeni ilişkilerin kurulmasına olanak sağlamaktadır. İnternet kullanıcılarının çoğu, fiziksel dünyada yaşananlardan nitelik olarak ayrı canlı çevrimiçi topluluklarının birer parçası durumuna gelmektedir. Bu şekilde bazı bilim insanları interneti insan yaşamına olumlu bir ek olarak görmekte ve onun sosyal ağlarımızı genişlettiğini ve zenginleştirdiğini öne sürmektedir (Giddens ve Suttom 2016: 792).

İkinci görüş, birinci görüşün aksine internet konusunda oldukça olumsuzdur. Çünkü bunlara göre insanlar, çevrimiçi iletişimde zaman harcadıkça ve günlük işlerini siber uzayda takip ettikçe, fiziksel dünyada daha az zaman harcayacaklardır. Bu nedenle bazı sosyologlar, internet teknolojisinin yaygınlaşmasına paralel olarak toplumsal yalnızlaşmanın da artabileceğinden endişe duymaktadır. Onlar, internet kullanan kişi sayısının artmasıyla birlikte kişilerin aile üyeleriyle ve arkadaşlarıyla daha az nitelikli zaman geçireceklerini düşünmektedir. Çalışan insanların çoğu internet aracılığı ile evde mesai bittikten sonra, e-postaları kontrol etmekte ve gün için de tamamlanamayan işleri sürdürmektedir. $\mathrm{Bu}$ şekilde internet, ev ve iş arasındaki farkı belirsizleştirmekte, ev yaşamına gizlice saldırmaktadır. Ayrıca kişisel ilişkiler zarar görmekte, tiyatro ve kitap okumak gibi geleneksel eğlence biçimleri etkilenmekte ve toplumsal yaşamın dokusu zayıflamaktadır (Giddens ve Suttom 2016: 792).

Her ne kadar internete ve internet kullanımına olumlu ya da olumsuz bakanlar olsa da kabul edilmesi gereken gerçek, iletişim kurma ve etkileşime geçme amaciyla internet kullanımının son zamanlarda oldukça artması, bu artışında sosyal ilişkileri tartışılır kılmasıdır. Çünkü birey sosyal ilişki kurarak değişip, gelişmekte veya sosyalleşmektedir. Günümüzde bireylerin en çok sosyal ilişkide bulunduğu yer ise, internet içeriğinde yer alan sosyal medyadır. 
Ayhan DEVER ve Mehmet KOCA, "Beden Eğitimi ve Spor Yüksek Okulu Öğrencilerinin Sosyal Medya Kullanımına Yönelik Düzeylerinin Değerlendirilmesi: Ordu Üniversitesi Örneği”, Mavi Atlas, 5(2)/2017: 383-401.

Bugün bireylerin çoğu zamanlarının büyük bir kısmını sosyal medyada geçirmekte ve bu şekilde sosyalleşmektedir. $\mathrm{Bu}$ da birçok tartışmayı beraberinde getirmektedir. Demir (2015: 148)'e göre, yeni iletişim teknolojileri ve sosyal medya bireylere eğlence, boş zamanlarını değerlendirme, heyecanlarını tatmin etme firsatı vermekte, etkin bir katılımcı olarak bireyler sanal ortamlarda, video oyunları ya da sanal çiftliklerde yetiştirdikleri hayvanlarla, bitkilerle, pişirdikleri yemeklerle kendileri için son derece heyecan verici ve eğlendirici kurguya dayalı ortamlar oluşturabilmektedir. Bu ilişkilerin tamamı sosyal kelimesinin farklılaşmasına yol açmakta, bireyin sosyal bir varlık olduğu gerçeğini dönüştürmektedir. Çağımızda önemli bir iletişim teknolojisi haline gelen sosyal medya, sosyal ilişkileri ve sosyal etkileşimleri doğrudan veya dolaylı olarak etkilemektedir.

$\mathrm{Bu}$ çerçevede Dellaloğlu sosyal medya konusuna uzaklık, yakınlık boyutuyla yaklaşmakta ve bazı sorular sormaktadır. Bunlar (Dellaloğlu 2015: 22): Sosyal medya, örneğin Facebook ve Twitter, modernliğin klasik toplumsallaştırma ortamlarının yeni teknolojik imkânlarla dönüşmüş bir hali midir? Yoksa bunları artık yepyeni bir toplumsallık olarak da değerlendirmek durumunda mıyı? O bu soruların cevabı olarak da ikincisini doğrulamaktadır.

Benzer şekilde Bezci (2015: 31)'de, “sosyal medya gerçekten zannedildiği gibi yeni bir toplumsallık oluşturuyor mu?" sorusunu sormakta ve yanıt olarak da "çok bireysel olanın toplumsal alana taşınması" cevabını vermektedir. Ona göre bu taşınma, yan yana duruşlar şeklinde herhangi bir ortaklık yaratmasa da gerçekten yeni bir dayanışma biçimi olarak bireysel olanı toplumsala taşımaktadır.

Anlaşılacağı üzere bireyler internetle bağlantı kurarken sosyal medya aracılığıyla belirli topluluklara da bağlanmakta ve bu şekilde sosyal paylaşım ağları sosyalleşmenin yeni bir öğesi olarak görülmekte ve tanımlanmaktadır. 
Ayhan DEVER ve Mehmet KOCA, "Beden Eğitimi ve Spor Yüksek Okulu Öğrencilerinin Sosyal Medya Kullanımına Yönelik Düzeylerinin Değerlendirilmesi: Ordu Üniversitesi Örneği”, Mavi Atlas, 5(2)/2017: 383-401.

\section{Sosyal (Medya) Paylaşım A ğları:}

Sosyal medya, temelinde katılımın ve paylaşımın yer aldığı, kullanıcıların çevirim içi olarak başka kullanıcılarla video, fotoğraf, metin ve haber paylaşabildiği Web sitelerine verilen ortak isimdir. Ayrıca sosyal medya, Web 2.0 tabanlı hizmetlerin yaygınlaştırılmasını ve üretilmesini sağlayan yeni iletişim ortamlarının genel adıdır (Kırık 2013: 74-75). Bilgi ve iletişim teknolojilerinde ortaya çıkan gelişmeler sayesinde insanların birbirleriyle iletişim kurmaları, bilgiye erişmeleri ve bilgiyi kullanma ve paylaşmaları kolay hale gelmiştir. Artık yaşadığımız dönemde bireyler Web 1.0 araçlarından ayrı olarak Web 2.0 araçlarını iletişimde, etkileşimde ve paylaşımda bulunma gibi farklı amaçlar için kullanmakta, böylece bir çok sosyal paylaşım ağı ortaya çıkmaktadır. Bu sosyal ağlardan en yaygın bilinenleri de, Facebook, Twitter, Youtube, (İnstagram), Blog, Flickr, Myspace ve Wiki'dir. Her ne kadar bu sosyal medya ağlarının her biri bazı ortak özelliklere sahip olsalar da, sosyal teknolojilerin kullanım amaçları farklılık göstermektedir (Alper 2012: 5). Bu çerçevede sosyal medya platformları "sosyal ăg siteleri, bloglar, mikrobloglar, içerik paylaşım siteleri, sosyal işaretleme siteleri, wiki, podcast, RSS ve forumlar olarak kategorilendirilebilir" (Yeniçıktı 2016: 95).

Dijital pazarlama ajansı 'We Are Social' tarafindan yayınlanan 2016 yılı Internet ve Sosyal Medya Kullanıcı Istatistikleri Raporu'na göre dünya genelinde 3.419 milyar insan internet kullanmakta ve bu internet kullanıcılarının 2.307 milyarı sosyal medyayı aktif bir şekilde takip etmektedir. Raporda ülkemizde ise 79,14 milyonluk nüfusun, 46,28 milyonunun internet kullandığı ve 42 milyon insanın diğer bir ifade ile toplum nüfusun \%58'inin aktif bir şekilde sosyal medyayı kullandığı belirtilmektedir. Ayrica sosyal medya kullanan 42 milyondan 36 milyonu ise sosyal medyayı mobil cihazlardan kontrol etmektedir. Yine rapor dâhilinde en fazla kullanılan sosyal medya platformlarına bakıldığında ise, Facebook, Whatsapp, Messenger, Twitter ve Instagram şeklinde bir siralama gönüu gülmektedir (https://www.slideshare.net/wearesocialsg/2016-digital-yearbook). 
Ayhan DEVER ve Mehmet KOCA, "Beden Eğitimi ve Spor Yüksek Okulu Öğrencilerinin Sosyal Medya Kullanımına Yönelik Düzeylerinin Değerlendirilmesi: Ordu Üniversitesi Örneği”, Mavi Atlas, 5(2)/2017: 383-401.

Bizde çalışmamızda bu ağların ve platformların hepsine yer vermek yerine en yaygın olarak kullanılan (çalışmanın sınırlılığı açısından) Facebook, Twitter ve Instagram'a k1saca yer vermeyi uygun bulduk.

2.1 Facebook: Sosyal ağlar içinde en önemlileri arasında yer alan Facebook, kişilerin diğer kişilerle metin, video ve resim gibi araçlarla iletişim kurmasına ve etkileşimde bulunmasına imkân tanıyan bir sosyal paylaşım ağıdır. Bu sosyal ağ Tiryaki (2015)'nin belirlemelerine göre, çevrimiçi düzenlemeleriyle kişilerle bağlantı kurmayı sağlayan bir sayfa olmanın ötesine geçmiştir. Eski arkadaşlara bakma ve sohbet etmenin yanı sıra e-posta gönderme ve alma, etkinliklere göz atma, alışveriş yapma ve iş bulmaya kadar birçok şeye firsat vermektedir. Taşınabilir cihazlarla ve cep telefonu ile bağlanılabilmektedir. Ayrıca Facebook sürekli olarak içeriğinde yapmış olduğu değişikliklerle dinamik, rekabetçi ve kullanışlı olarak bilinmektedir. Facebook kullanıcıları, fotoğraf, yaş, cinsiyet, eğitim durumu, ilgi alanları gibi kişisel özelliklerin yer aldığı profiller oluşturabilmekte, özel veya herkese açık genel olarak mesajlar göndererek farklı arkadaşlık gruplarına katılabilmektedir. Facebook’un kullanıcıları destekleyici bir özelliği vardır.

2.2 Twitter: Faecebook'un ardından 2006 yılında hizmete giren, kullanıcılarına 140 karakterlik söz edim olanağı tanıyan ve bu söz edimlerinin "tweet" olarak adlandırıldığı bir diğer sosyal paylaşım ağı da Twitter'dır. Bu paylaşım ağı, hızlı biçimde değişen, bilgi ve fikirlerin değiş tokuş edildiği, insanları tanıdıkları olsun olmasın ilgi duydukları kişilerle bilgisayardan ya da cep telefonundan buluşturmaktadır.

$\mathrm{Bu}$ çerçevede insanların Twitter'ı kullanmalarının değişik nedenleri vardır. Bunlar (Fitton Vd.'den Akt., Tiryaki 2015: 123-124):

a- Bağlantı Kurmak: Pek çok insan bağlantılar kurmak ve bir topluluğun parçası olabilmek için Twitter kullanırken bazıları ise seslerini duyurmak için kullanırlar. Dünya genelinde milyonlarca kişinin, diğerinin ne söylediğini duymasina firsat verir. 
Ayhan DEVER ve Mehmet KOCA, "Beden Eğitimi ve Spor Yüksek Okulu Öğrencilerinin Sosyal Medya Kullanımına Yönelik Düzeylerinin Değerlendirilmesi: Ordu Üniversitesi Örneği”, Mavi Atlas, 5(2)/2017: 383-401.

b- Kayıt Düşmek: Bazı insanlar hayata dair notlar almak için tweet atarlar. Bu kişiler etkinlikte ya da bir konferansta olan bir şeyi veya keşfettikleri bir şeyi tweetlerler.

c- Bă̆lantıda kalmak: Twitter bağlantıları korumanın en iyi araçlarından biridir. Tüm aileler ve uzun süreden beri arkadaş olanlar Twitter'i bağlantıda kalmak için kullanır. Bu paylaşım ağında herkes için mesaj atılabilirken, özel olarak da mesaj atılabilir ve tüm bunlar depolanabilir.

d- Bazı insanlar bu paylaşım ağını, düşündüklerini, bildiklerini ve okuduklarını paylaşmak için kullanırlar.

Her ne kadar yapılan araştırmalar en çok takip edilen on Twitter kullanıcısının dokuzunun eğlenceye yönelik olduğunu gösterse de (Fuchs 2014: 138), son zamanlarda Tiwitter'ın belli bir düşünceyi veya ideolojiyi yaymak ve geniş kesimleri etkilemek içinde kullanıldığg görülmektedir. Örneğin Tumajsan ve Vd. (2010: 178)'nin belirttikleri üzere, 2008 yılında Barack Obama ve ekibi bu paylaşım ağını kullanarak Amerika başkanlık seçimi kampanyasının içeriğini duyurmak ve vatandaşların seçim sürecine ilişkin tepkilerini ölçmek için oldukça başarılı bir biçimde kullanmıştır

2.3 Instagram: Yeniçıktı (2016: 94)'nın belirlemelerine göre, “mobil sosyal ağ sitesi olan Instagram 2010 yılında kuruldu ve 2012 yılında Facebook tarafindan satın alındı. Instagram bir fotoğraf ve video paylaşım platformu olmasının yanı sıra kullanıcıların akıllı telefon uygulaması yoluyla fotoğraflara dijital filtrelerden bir seçim uygulandıktan sonra fotoğrafların paylaşılmasına ya da alınmasına olanak tanıyan bir sosyal ă̆ sitesidir. Bu fotoğrafların Facebook, Twitter gibi sosyal ağ sitelerinde kolayca paylaşılmasını sağlar.” Bu paylaşım ağının en büyük özelliklerinden biri, insanların yaşamlarından fotoğraflar paylaşarak bu fotoğrafların, diğer insanların beğeni veya yorumlarına anlık olarak sunulmasıdır. 
Ayhan DEVER ve Mehmet KOCA, "Beden Eğitimi ve Spor Yüksek Okulu Öğrencilerinin Sosyal Medya Kullanımına Yönelik Düzeylerinin Değerlendirilmesi: Ordu Üniversitesi Örneği”, Mavi Atlas, 5(2)/2017: 383-401.

\section{YÖNTEM}

\subsection{Araştırmanın Evren ve Örneklemi}

Çalı̧̧manın evrenini Ordu Üniversitesi Beden Eğitimi ve Spor Yüksekokulu öğrencileri oluşturmaktadır. Araştırma örneklemi rastgele örnekleme yöntemi kullanılarak oluşturulmuştur. Bu bağlamda toplam 206 Beden Eğitimi ve Spor Yüksekokulu öğrencisi ile görüşülmüştür.

\subsection{Veri Toplama Araçları:}

Çalışmada kullanılan veri toplama aracı iki bölümden oluşan bir anket formudur. Araştırmacılar anketlerin uygulanacağı katılımcılara, anket öncesi konuyla ilgili bilgi vermiş, anketin açıklamasını yapmış ve sonrasında soruların katılımcılar tarafından sağlıklı bir şekilde cevaplanmasına yardımcı olmuştur. Anket formunun ilk bölümünde katılımcılara ilişkin sosyo - demografik sorular sorulmuştur.

İkinci bölümde ise Otrar ve Arkın $^{1}$ tarafından geliştirilen Sosyal Medya Kullanımına Yönelik Tutum Ölçeği kullanılmıştır. Ölçek 35 maddeden oluşan 5’li likert tipi ölçektir.

Sosyal Medya Kullanımına Yönelik Tutum Ölçeği; düşkünlük, eğlence ve paylaşım, ilgi çekme, sosyal etkileşim, açık iletişim ve eğitim olmak üzere toplam altı alt boyuttan oluşmaktadır. Ölçekte; düşkünlük alt boyutu ile ilgili 13 madde, eğlence ve paylaşım ile ilgili 8 madde, ilgi çekme ile ilgili 5 madde, sosyal etkileşim, açık iletişim ve eğitim ile ilgili 3'er madde yer almaktadır. Çalışmada her bir faktörün iç tutarlılığı Cronbach alfa katsayısı ile ölçülmüş ve tüm ölçek için elde edilen alfa değeri ,908 olarak tespit edilmiştir. Otrar ve Argın, ölçeğin tutarlı olabilmesi için Cronbach alfa sayısının 0,661 ila 0,916 arasında olması gerektiğini belirtmişlerdir.

\footnotetext{
${ }^{1}$ Otrar, M. - Argın, F. S. (2016). Sosyal Medya Kullanımına Yönelik Tutum Ölçeğinin Geçerlilik ve Güvenirlilik Çalışması, III. International Eurasian Educational Research Congress, Muğla.
} 
Ayhan DEVER ve Mehmet KOCA, "Beden Eğitimi ve Spor Yüksek Okulu Öğrencilerinin Sosyal Medya Kullanımına Yönelik Düzeylerinin Değerlendirilmesi: Ordu Üniversitesi Örneği”, Mavi Atlas, 5(2)/2017: 383-401.

\section{3. İstatistiksel analiz}

Veri dağılımın normalliği Kolmogorov Smirnov testi incelenmiş ve verilerin normal dağılım gösterdiği belirlenmiştir. Verilerin analizinde ikili grupların karşılaştırılması için ilişsisiz örneklemler için T-testi, ikiden fazla grupların karşılaştırılmasında ise tek yönlü varyans analizi (ANOVA) kullanılmıştır. Varyans analizi sonucunda gruplar arası farklılığın görüldüğü durumlarda, farklılığın hangi gruplar arasında olduğunu belirlemek amacıyla Tukey HSD testinden yararlanılmıştır.

\section{BULGULAR}

\subsection{Betimsel İstatistik}

Araştırmaya toplam 76 kadın, 130 erkek katılmıştır. Araştırmaya katılan bireylerin, annelerinin eğitim durumuna bakıldığında büyük bir çoğunluğun sırasıyla ilköğretim $(\% 56,8)$ ve ortaöğretim $(\% 31,6)$ mezunu olduğu görülmektedir. Araştırmaya katılan bireylerin, babalarının eğitim durumuna bakıldığında ise çoğunluğun sırasıyla ortaöğretim (\%49) ve ilköğretim $(\% 38,8)$ mezunu oldukları anlaşılmaktadır. Araştırmaya katılan bireylerin ailelerinin aylık toplam gelirlerine bakıldığında ise ağırlığın 1501 - 2501 TL $(\% 36,4)$ ve 1001 - 1500 TL $(\% 26,2)$ arasında olduğunu görmekteyiz. Ayrıca 2501 ve üzeri gelire sahip olanların toplam oranı ise \%26,7 olarak hesaplanmıştır.

Ayrıca araştırmaya katılan bireyler sırasıyla ilçe (\%37,4), şehir (\%33), büyükşehir (\%16) ve köy - kasaba $(\% 13,6)$ 'da yaşamaktadırlar. Araştırmaya katılan bireylerin \%17'si milli sporcudur. Araştırmaya katılan bireyler daha fazla oranda $(\% 44,7)$ takım sporları ile ilgilenmektedirler.

Araştırmaya katılan bireylerin sosyal medyayı nereden takip ettiklerine bakıldığında ise oldukça yüksek oranda (\%83) cep telefonu cevabıyla karşılaşılmıştır. Ardından bilgisayar $(\% 9,7)$ ve tablet $(\% 3,9)$ cevapları verilmiştir. Araştırmaya katılan bireylerin en fazla takip ettiği sosyal medya platformlarına bakıldığında ise en yüksek oranda $(\% 55,8)$ Instagram'1 görmekteyiz. Sonrasında Facebook $(\% 23,3)$ ve Twitter 
Ayhan DEVER ve Mehmet KOCA, “Beden Eğitimi ve Spor Yüksek Okulu Öğrencilerinin Sosyal Medya Kullanımına Yönelik Düzeylerinin Değerlendirilmesi: Ordu Üniversitesi Örneği”, Mavi Atlas, 5(2)/2017: 383-401.

$(12,6)$ gelmektedir. Araştırmaya katılan bireyler, sosyal medyada çoğunlukla $(\% 60,7) 1$ 3 saat arasında süre geçirmektedirler. Ayrıca 4-6 saat arasında zaman geçirdiğini söyleyenlerin oran1 \%28,4'tür (Bkz.: Tablo 1).

Tablo 1: Katılımcıların Sosyo - Demoğrafik Özellikleri

\begin{tabular}{|c|c|c|}
\hline & Sayı & Yüzde \\
\hline \multicolumn{3}{|l|}{ Cinsiyet } \\
\hline Kadin & 76 & 36,9 \\
\hline Erkek & 130 & 62,1 \\
\hline \multicolumn{3}{|l|}{ Annenin Eğitim Durumu } \\
\hline İlköğretim & 117 & 56,8 \\
\hline Ortaöğretim & 65 & 31,6 \\
\hline Önlisans & 8 & 3,9 \\
\hline Lisans & 14 & 6,8 \\
\hline Yüksekslisans/Doktora & 2 & 1 \\
\hline \multicolumn{3}{|l|}{ Babanın Eğitim Durumu } \\
\hline İlköğretim & 80 & 38,8 \\
\hline Ortaöğretim & 101 & 49 \\
\hline Önlisans & 9 & 4,4 \\
\hline Lisans & 12 & 5,8 \\
\hline Yüksekslisans/Doktora & 4 & 1,9 \\
\hline \multicolumn{3}{|l|}{ Ailenin Aylık Geliri } \\
\hline $0-500$ & 8 & 3,9 \\
\hline $501-1000$ & 14 & 6,8 \\
\hline $1001-1500$ & 54 & 26,2 \\
\hline $1501-2500$ & 75 & 36,4 \\
\hline $2501-4000$ & 36 & 17,5 \\
\hline 4001 ve Üstü & 19 & 9,2 \\
\hline \multicolumn{3}{|l|}{ Yaşadığınız Yer } \\
\hline Köy - Kasaba & 28 & 13,6 \\
\hline İlçe & 77 & 37,4 \\
\hline Şehir & 68 & 33 \\
\hline Büyükşehir & 33 & 16 \\
\hline \multicolumn{3}{|l|}{ Milli Sporcu Olma Durumu } \\
\hline Evet & 35 & 17 \\
\hline Hayır & 171 & 83 \\
\hline \multicolumn{3}{|l|}{ İlgilendiğiniz Spor Branşı } \\
\hline Takım Sporları (Futbol, voleybol vb.) & 92 & 44,7 \\
\hline Bireysel Sporlar (Boks, Güreş, judo vb) & 65 & 31,6 \\
\hline Spor Yapmam & 49 & 23,8 \\
\hline \multicolumn{3}{|l|}{ Sosyal Medyayı Nerden Takip Edersin } \\
\hline Bilgisayar & 20 & 9,7 \\
\hline Tablet & 8 & 3,9 \\
\hline Cep Telefonu & 173 & 84 \\
\hline Diğger & 5 & 2,4 \\
\hline \multicolumn{3}{|l|}{ En Çok Takip Ettiğiniz Sosyal Medya Platformu } \\
\hline Facebook & 48 & 23,3 \\
\hline Twitter & 26 & 12,6 \\
\hline Instagram & 115 & 55,8 \\
\hline Diğer & 17 & 8,3 \\
\hline
\end{tabular}


Ayhan DEVER ve Mehmet KOCA, “Beden Eğitimi ve Spor Yüksek Okulu Öğrencilerinin Sosyal Medya Kullanımına Yönelik Düzeylerinin Değerlendirilmesi: Ordu Üniversitesi Örneği”, Mavi Atlas, 5(2)/2017: 383-401.

\begin{tabular}{ccc} 
Hiç Giriş Yapmam & 11 & 5,3 \\
$1-3$ saat & 125 & 60,7 \\
4-6 saat & 58 & 28,2 \\
$7-9$ saat & 9 & 4,4 \\
10 saat ve yukarısı & 3 & 1,5 \\
Toplam & 206 & 100 \\
\hline
\end{tabular}

\subsection{Açıklayıcı istatistik}

H1: Sosyal medya kullanma durumu cinsiyete göre farklılaşmaktadır.

Sosyal medya kullanım durumunun cinsiyete göre farklılaşıp farklılaşmadığı ilişkisiz örneklemler için T-Testi ile ortaya konmuştur. Sosyal medyayı kullanma durumu; düşkünlük, eğlence, paylaşım, açık iletişim ve eğitim alt boyutlarında cinsiyete göre grıplar arasında farklılık göstermezken (p>.05), ilgi çekme ve sosyal etkileşim alt boyutları bakımından gruplar arasında farklılık göstermektedir $(\mathrm{p}<.05)$. Ölçek alt boyutlarından alınan ortalama puanlar göz önüne alındığında, ilgi çekme ve sosyal etkileşim alt boyutlarında erkeklerin (ilgi çekme alt boyutu için ort.: 15.92, sosyal etkileşim alt boyutu için ort.: 9.30), kadınlardan daha yüksek puan aldığı görülmektedir (Bkz.:Tablo 2). Buradan hareketle erkeklerin, sosyal medyayı çoğunlukla ilgi çekme ve sosyal etkileşim amaçlı olarak kullandıkları sonucuna ulaşılmıştır.

Tablo 2: Sosyal Medyayı Kullanma Durumu ve Cinsiyet: Bağımsız Örnekleme T Testi

\begin{tabular}{|c|c|c|c|c|c|c|}
\hline & Cinsiyet & $\mathrm{N}$ & Ort. & ss. & $\mathrm{t}$ & $\mathrm{p}$ \\
\hline \multirow[t]{2}{*}{ Düşkünlük Toplam } & Kadın & 76 & 34,14 & 12,026 &,- 333 & ,739 \\
\hline & Erkek & 130 & 34,71 & 11,77 & & \\
\hline \multirow[t]{2}{*}{ Eğlence Paylaşım Toplam } & Kadın & 76 & 27,06 & 7,52 &,- 619 & ,537 \\
\hline & Erkek & 130 & 27,67 & 6,40 & & \\
\hline \multirow[t]{2}{*}{ İlgi Çekme Toplam } & Kadın & 76 & 14,35 & 4,72 & $-2,674$ & ,008 \\
\hline & Erkek & 130 & 15,92 & 3,62 & & \\
\hline \multirow[t]{2}{*}{ Sosyal Etkileşim Toplam } & Kadın & 76 & 7,96 & 2,93 & $-3,482$ &, 001 \\
\hline & Erkek & 130 & 9,30 & 2,49 & & \\
\hline \multirow[t]{2}{*}{ Açık İletişim Toplam } & Kadın & 76 & 9,34 & 2,88 &,- 600 & 549 \\
\hline & Erkek & 130 & 9,58 & 2,75 & & \\
\hline
\end{tabular}


Ayhan DEVER ve Mehmet KOCA, “Beden Eğitimi ve Spor Yüksek Okulu Öğrencilerinin Sosyal Medya Kullanımına Yönelik Düzeylerinin Değerlendirilmesi: Ordu Üniversitesi Örneği”, Mavi Atlas, 5(2)/2017: 383-401.

\begin{tabular}{|lc|c|c|c|c|c|}
\hline Eğitim Toplam & Kadın & 76 & 8,18 & 2,63 & $-1,644$ &, 102 \\
& Erkek & 130 & 8,79 & 2,52 & & \\
\hline
\end{tabular}

H2: Sosyal medya kullanma durumu annenin eğitim durumuna göre farklılaşmaktadır.

Sosyal medya kullanım ölçeğinin alt boyutlarının, annenin eğitim durumuna göre gruplar arasında farklılık gösterip göstermediği tek yönlü varyans analizi (ANOVA) ile test edilmiştir (Bkz: Tablo 3). Elde edilen bulgular, sosyal medya kullanma durumunun annenin eğitim durumuna göre gruplar arasında farklılık göstermediğini ortaya koymaktadır ( $\mathrm{p}>.05)$.

Tablo 3: Sosyal Medya Kullanımına Yönelik Tutumu Annenin Eğitim Durumu: One - Way Anova Analizi Sonuçları

\begin{tabular}{|c|c|c|c|c|c|c|}
\hline & & $\begin{array}{l}\text { Kareler } \\
\text { Toplamı }\end{array}$ & $\mathrm{Sd}$ & Kare Ortalaması & $\mathrm{F}$ & Sig. \\
\hline \multirow[t]{3}{*}{ Açık İletişim Toplam } & Gruplar Arası & 37,15 & 3 & 12,38 & 1,599 & , 191 \\
\hline & Gruplar İçi & 1564,34 & 202 & 7,74 & & \\
\hline & Toplam & 1601,49 & 205 & & & \\
\hline \multirow[t]{3}{*}{ Sosyal Etkileşim Toplam } & Gruplar Aras1 & 11,67 & 3 & 3,89 & ,516 & ,671 \\
\hline & Gruplar İçi & 1522,55 & 202 & 7,53 & & \\
\hline & Toplam & 1534,23 & 205 & & & \\
\hline \multirow[t]{3}{*}{ İlgi Çekme Toplam } & Gruplar Arası & 104,27 & 3 & 34,76 & 2,080 & 104 \\
\hline & Gruplar İçi & 3376,25 & 202 & 16,71 & & \\
\hline & Toplam & 3480,52 & 205 & & & \\
\hline \multirow[t]{3}{*}{ Eğlence Paylaşım Toplam } & Gruplar Arası & 212,67 & 3 & 70,89 & 1,532 & 207 \\
\hline & Gruplar İçi & 9344,34 & 202 & 46,25 & & \\
\hline & Toplam & 9557,01 & 205 & & & \\
\hline \multirow[t]{3}{*}{ Düşkünlük Toplam } & Gruplar Arası & 498,71 & 3 & 166,23 & 1,189 & ,315 \\
\hline & Gruplar İçi & 28246,78 & 202 & 139,83 & & \\
\hline & Toplam & 28745,49 & 205 & & & \\
\hline \multirow[t]{3}{*}{ Eğitim Toplam } & Gruplar Arası & 17,96 & 3 & 5,99 & ,904 & ,440 \\
\hline & Gruplar İçi & 1338,58 & 202 & 6,62 & & \\
\hline & Toplam & 1356,54 & 205 & & & \\
\hline
\end{tabular}


Ayhan DEVER ve Mehmet KOCA, “Beden Eğitimi ve Spor Yüksek Okulu Öğrencilerinin Sosyal Medya Kullanımına Yönelik Düzeylerinin Değerlendirilmesi: Ordu Üniversitesi Örneği”, Mavi Atlas, 5(2)/2017: 383-401.

H3: sosyal medya kullanma durumu babanın eğitim düzeyine göre farklılaşmaktadır.

Sosyal medya kullanım ölçeğinin alt boyutlarının, babanın eğitim durumuna göre gruplar arasında farklılık gösterip göstermediği tek yönlü varyans analizi (ANOVA) ile test edilmiştir (Bkz: Tablo 4). Elde edilen bulgular, sosyal medya kullanma durumunun babanın eğitim durumuna göre gruplar arasında farklılık göstermediğini ortaya koymaktadır ( $\mathrm{p}>.05)$.

Tablo 4: Sosyal Medya Kullanımına Yönelik Tutumu ve Babanın Eğitim Durumu: One - Way Anova Analizi Sonuçları

\begin{tabular}{|c|c|c|c|c|c|c|}
\hline & & $\begin{array}{l}\text { Kareler } \\
\text { Toplamı }\end{array}$ & $\mathrm{Sd}$ & $\begin{array}{c}\text { Kare } \\
\text { Ortalamas1 }\end{array}$ & $\mathrm{F}$ & Sig. \\
\hline \multirow[t]{3}{*}{ Açık İletişim Toplam } & Gruplar Arası & 10,03 & 4 & 2,510 & ,317 & ,866 \\
\hline & Gruplar İçi & 1591,45 & 201 & 7,918 & & \\
\hline & Toplam & 1601,49 & 205 & & & \\
\hline \multirow[t]{3}{*}{ Sosyal Etkileşim Toplam } & Gruplar Arası & 19,24 & 4 & 4,812 & ,638 & ,636 \\
\hline & Gruplar İçi & 1514,98 & 201 & 7,537 & & \\
\hline & Toplam & 1534,23 & 205 & & & \\
\hline \multirow[t]{3}{*}{ İlgi Çekme Toplam } & Gruplar Aras1 & 38,62 & 4 & 9,657 &, 564 & ,689 \\
\hline & Gruplar İçi & 3441,90 & 201 & 17,124 & & \\
\hline & Toplam & 3480,52 & 205 & & & \\
\hline \multirow[t]{3}{*}{ Eğlence Paylaşım Toplam } & Gruplar Arası & 63,82 & 4 & 15,957 & ,338 &, 852 \\
\hline & Gruplar İçi & 9493,18 & 201 & 47,230 & & \\
\hline & Toplam & 9557,01 & 205 & & & \\
\hline \multirow[t]{3}{*}{ Düşkünlük Toplam } & Gruplar Aras1 & 227,89 & 4 & 56,972 & ,402 & ,807 \\
\hline & Gruplar İçi & 28517,60 & 201 & 141,879 & & \\
\hline & Toplam & 28745,49 & 205 & & & \\
\hline \multirow[t]{3}{*}{ Eğitim Toplam } & Gruplar Arası & 2,196 & 4 & ,549 & ,081 & ,988 \\
\hline & Gruplar İçi & 1354,353 & 201 & 6,738 & & \\
\hline & Toplam & 1356,549 & 205 & & & \\
\hline
\end{tabular}


Ayhan DEVER ve Mehmet KOCA, “Beden Eğitimi ve Spor Yüksek Okulu Öğrencilerinin Sosyal Medya Kullanımına Yönelik Düzeylerinin Değerlendirilmesi: Ordu Üniversitesi Örneği”, Mavi Atlas, 5(2)/2017: 383-401.

H4: sosyal medya kullanma durumu ailenin gelir düzeyine göre farklılaşmaktadır.

Sosyal medya kullanım ölçeğinin alt boyutlarının, ailenin gelir düzeyine göre farklılık gösterip göstermediği tek yönlü varyans analizi (ANOVA) ile test edilmiştir (Bkz: Tablo 5). Elde edilen bulgular, sosyal medya kullanma durumunun, ailenin gelir durumuna göre gruplar arasında farklılık göstermediğini ortaya koymaktadır ( $p>.05)$.

Tablo 5: Sosyal Medya Kullanımına Yönelik Tutum ve Gelir Grupları: One - Way Anova Analizi Sonuçları

\begin{tabular}{|c|c|c|c|c|c|c|}
\hline & & $\begin{array}{l}\text { Kareler } \\
\text { Toplamı }\end{array}$ & $\mathrm{Sd}$ & $\begin{array}{c}\text { Kare } \\
\text { Ortalamas1 }\end{array}$ & $\mathrm{F}$ & Sig. \\
\hline \multirow[t]{3}{*}{ Açık İletişim Toplam } & Gruplar Arası & 18,582 & 4 & \multirow{3}{*}{$\begin{array}{l}4,646 \\
7,875\end{array}$} & \multirow[t]{3}{*}{,590 } & \multirow[t]{3}{*}{670} \\
\hline & Gruplar İçi & 1582,913 & 201 & & & \\
\hline & Toplam & 1601,495 & 205 & & & \\
\hline \multirow[t]{3}{*}{ Sosyal Etkileşim Toplam } & Gruplar Arası & 5,069 & 4 & \multirow{3}{*}{$\begin{array}{l}1,267 \\
7,608\end{array}$} & \multirow[t]{3}{*}{, 167} & \multirow[t]{3}{*}{,955 } \\
\hline & Gruplar İçi & 1529,164 & 201 & & & \\
\hline & Toplam & 1534,233 & 205 & & & \\
\hline \multirow[t]{3}{*}{ İlgi Çekme Toplam } & Gruplar Arası & 47,345 & 4 & \multirow{3}{*}{$\begin{array}{l}11,836 \\
17,081\end{array}$} & \multirow[t]{3}{*}{,693 } & \multirow[t]{3}{*}{,598 } \\
\hline & Gruplar İçi & 3433,185 & 201 & & & \\
\hline & Toplam & 3480,529 & 205 & & & \\
\hline \multirow[t]{3}{*}{ Eğlence Paylaşım Toplam } & Gruplar Arası & 84,015 & 4 & \multirow{3}{*}{$\begin{array}{l}21,004 \\
47,129\end{array}$} & \multirow[t]{3}{*}{,446 } & \multirow[t]{3}{*}{,775 } \\
\hline & Gruplar İçi & 9473,000 & 201 & & & \\
\hline & Toplam & 9557,015 & 205 & & & \\
\hline \multirow[t]{3}{*}{ Düşkünlük Toplam } & Gruplar Arası & 272,146 & 4 & \multirow{3}{*}{$\begin{array}{c}68,037 \\
141,658\end{array}$} & \multirow[t]{3}{*}{,480 } & \multirow[t]{3}{*}{, 750} \\
\hline & Gruplar İçi & 28473,349 & 201 & & & \\
\hline & Toplam & 28745,495 & 205 & & & \\
\hline \multirow[t]{3}{*}{ Eğitim Toplam } & Gruplar Aras1 & 17,908 & 4 & \multirow{3}{*}{$\begin{array}{l}4,477 \\
6,660\end{array}$} & \multirow[t]{3}{*}{,672 } & \multirow[t]{3}{*}{,612 } \\
\hline & Gruplar İçi & 1338,640 & 201 & & & \\
\hline & Toplam & 1356,549 & 205 & & & \\
\hline
\end{tabular}

H5: sosyal medya kullanım durumu kişilerin yaşadığı yere göre farklılaşmaktadır. 
Ayhan DEVER ve Mehmet KOCA, “Beden Eğitimi ve Spor Yüksek Okulu Öğrencilerinin Sosyal Medya Kullanımına Yönelik Düzeylerinin Değerlendirilmesi: Ordu Üniversitesi Örneği”, Mavi Atlas, 5(2)/2017: 383-401.

Sosyal medya kullanım durumunun bireyin yaşadığı yere göre farklılığı tek yönlü varyans analizi (ANOVA) ile test edilmiştir (Tablo 6). Sosyal medyayı kullanma durumu; düşkünlük, eğlence paylaşım, açık iletişim ve eğitim alt boyutları bakımından, kişinin yaşadığı yere göre gruplar arasında farklılık göstermemektedir ( $\mathrm{p}>.05)$.

Ancak ilgi çekme alt boyutu bakımından gruplar arasında farklılık gözlenmektedir $(\mathrm{p}<.05)$. Farklılığın hangi gruplar arasında olduğunu saptamak amacıyla yapılan post-hoc (çoklu karşılaştırma) testi sonuçlarına göre, farklılıklar köy ve kasabada yaşayanlar ile ilçe ve büyükşehirlerde yaşayan gruplar arasındadır. İlçelerde yaşayanlar, diğer gruplara göre sosyal medyayı daha çok ilgi çekme amaçlı kullanmaktadır.

Tablo 6: Sosyal Medya Kullanımına Yönelik Tutumu ile Bireyin Yașadığı Yer: One - Way Anova Analizi Sonuçları

\begin{tabular}{|c|c|c|c|c|c|c|}
\hline & & $\begin{array}{l}\text { Kareler } \\
\text { Toplamı }\end{array}$ & $\mathrm{Sd}$ & $\begin{array}{c}\text { Kare } \\
\text { Ortalamas1 }\end{array}$ & $\mathrm{F}$ & Sig. \\
\hline \multirow[t]{3}{*}{ Açık İletişim Toplam } & Gruplar Arası & 44,425 & 3 & 14,808 & 1,921 &, 127 \\
\hline & Gruplar İçi & 1557,070 & 202 & 7,708 & & \\
\hline & Toplam & 1601,495 & 205 & & & \\
\hline \multirow[t]{3}{*}{ Sosyal Etkileşim Toplam } & Gruplar Aras1 & 42,370 & 3 & 14,123 & 1,912 &, 129 \\
\hline & Gruplar İçi & 1491,863 & 202 & 7,385 & & \\
\hline & Toplam & 1534,233 & 205 & & & \\
\hline \multirow[t]{3}{*}{ İlgi Çekme Toplam } & Gruplar Arası & 133,397 & 3 & 44,466 & 2,684 & ,048 \\
\hline & Gruplar İçi & 3347,132 & 202 & 16,570 & & \\
\hline & Toplam & 3480,529 & 205 & & & \\
\hline \multirow[t]{3}{*}{ Eğlence Paylaşım Toplam } & Gruplar Arası & 307,804 & 3 & 102,601 & 2,241 &, 085 \\
\hline & Gruplar İçi & 9249,210 & 202 & 45,788 & & \\
\hline & Toplam & 9557,015 & 205 & & & \\
\hline \multirow[t]{3}{*}{ Düşkünlük Toplam } & Gruplar Aras1 & 135,420 & 3 & 45,140 & ,319 & ,812 \\
\hline & Gruplar İçi & 28610,075 & 202 & 141,634 & & \\
\hline & Toplam & 28745,495 & 205 & & & \\
\hline \multirow[t]{3}{*}{ Eğitim Toplam } & Gruplar Arası & 9,059 & 3 & 3,020 & ,453 & ,716 \\
\hline & Gruplar İçi & 1347,489 & 202 & 6,671 & & \\
\hline & Toplam & 1356,549 & 205 & & & \\
\hline
\end{tabular}


Ayhan DEVER ve Mehmet KOCA, “Beden Eğitimi ve Spor Yüksek Okulu Öğrencilerinin Sosyal Medya Kullanımına Yönelik Düzeylerinin Değerlendirilmesi: Ordu Üniversitesi Örneği”, Mavi Atlas, 5(2)/2017: 383-401.

H6: Sosyal medya kullanım durumu milli sporcu olma durumuna göre farklılaşmaktadır.

Sosyal medya kullanım ölçeğinin alt boyutlarının bireyin milli sporcu olma durumuna göre farklılığı, ilişkisiz örneklemler için T-testi ile analiz edilmiştir (Bkz: Tablo 7). Elde edilen bulgular, sosyal medya kullanma durumunun, bireyin milli sporcu olma durumuna göre gruplar arasında farklılık göstermediğini ortaya koymaktadır ( $>$.05).

Tablo 7: Sosyal Medyayı Kullanma Durumu ve Milli Sporcu Olup Olmama: Bağımsız Örneklme T

\begin{tabular}{|ll|r|r|r|r|r|}
\hline & Milli sporcu & \multicolumn{1}{c|}{ Testi } & \multicolumn{1}{c|}{ Ort. } & ss & t & p \\
\hline Düşkünlük Toplam & Evet & 35 & 33,14 & 10,56 &,- 746 &, 456 \\
& Hayır & 171 & 34,78 & 12,09 & & \\
\hline Eğlence Paylaşım Toplam & Evet & 35 & 27,62 & 6,615 &, 168 &, 867 \\
& Hayır & 171 & 27,415 & 6,88 & &, 300 \\
\hline İlgi Çekme Toplam & Evet & 35 & 14,68 & 3,29 & $-1,039$ & \\
& Hayır & 171 & 15,47 & 4,26 & &, 675 \\
\hline Sosyal Etkileşim Toplam & Evet & 35 & 8,62 & 2,71 &,- 420 & \\
& Hayır & 171 & 8,84 & 2,74 & &, 775 \\
\hline Açık İletişim Toplam & Evet & 35 & 9,37 & 2,38 &,- 287 & \\
& Hayır & 171 & 9,52 & 2,87 & &, 467 \\
\hline Eğitim Toplam & Evet & 35 & 8,85 & 2,39 &, 729 & \\
\hline
\end{tabular}

\section{Sonuç ve Değerlendirme}

Sosyal medya platformu kullanımı, internetin daha kolay bir şekilde ulaşılabilir bir hale gelmesi ve bilgisayar, tablet ve akıllı cep telefonu kullanımının yaygınlaşması ile beraber daha da artmıştır. Her birey kendisine has özellikler taşıyan sosyal medya hesabında paylaşımlar yapmakta ve bu şekilde sosyal medyada da varlığını ortaya koymaktadır. Buna bağlı olarak dünya genelinde artan bir hızla yayılan sosyal medya kullanımı konusunda çalışmaların sayısıda artmıştır. 
Ayhan DEVER ve Mehmet KOCA, "Beden Eğitimi ve Spor Yüksek Okulu Öğrencilerinin Sosyal Medya Kullanımına Yönelik Düzeylerinin Değerlendirilmesi: Ordu Üniversitesi Örneği”, Mavi Atlas, 5(2)/2017: 383-401.

$\mathrm{Bu}$ çalışmada Ordu Üniversitesi Beden Eğitimi ve Spor Yüksekokulu öğrencilerinin, sosyal medya kullanımlarına yönelik tutumları ortaya konmaya çalışılmıştır. Öncelikli olarak araştırmaya katılan bireylerin büyük çoğunluğunun erkeklerden oluştuğu görülmüştür. Arştırmaya katılan bireylerin ailelerinin aylık geliri büyük oranda 1001 TL ve üzeridir. Araştırmaya katılan bireylerin doğduğu ve ailesiyle birlikte yaşadığı yerler büyük oranda ilçe ve şehirlerdir.

Araştırmaya katılan bireyler, sosyal medyayı büyük oranda cep telefonlarından takip etmektedirler. Diğer bir ifade araştırmaya katılanların tamamına yakını akıllı cep telefonlarına sahiptir. Sosyal medya platformları arasında resimlerin paylaşıldığı Instagram platformu takip edilmektedir. Sonrasında ise Facebook ve Twitter kullanımı gelmektedir. Araştırmaya katılan bireyler, sosyal medyada çoğunlukla 1-3 saat arasında kalmaktadırlar. Buna karşılık araştırmaya katılanların yine önemli bir kısmı 4-6 saat sosyal medyayı kullanmaktadırlar. Bu saat dilimi ise yadsınamayacak bir boyuttadır. Zira sosyal medyada geçirilen bu zaman dilimi içerisinde bireyler, gündelik hayattan kopmakta ve sanal gerçekliğin içerisinde hapsolmaktadırlar.

Araştırmaya katılan bireylerin sosyal medyayı kullanma durumlarının cinsiyete göre farklılığı incelendiğinde, özellikle ilgi çekme ve sosyal etkileşim alt ölçeklerinde erkek ve kadın katılımcılar arasında farklılık olduğu sonucuna ulaşılmıştır. Buna göre araştırmaya katılan erkekler, araştırmaya katılan kadın katılımcılara nazaran ilgi çekmek ve sosyal etkileşim sağlamak amacıyla sosyal medyayı kullanmaktadırlar. Diğer bir ifade ile erkek katılımcılar sosyal medyayı, ilgiyi arttırıcı ve sosyal etkileşimin sağlandığı bir faaliyet alanı olarak algılamaktadırlar.

Buna karışılık araştırmaya katılan bireylerin sosyal medyayı kullanma durumlarının, anne ve babalarının eğitim durumlarına göre bir farklılık göstermediği anlaşılmıştır. Bu sonuç üzerinde, sosyal medya kullanımının, anne - baba eğitim durumu ile bir ilişkisinin olmamasının ve bireylerin gerek teknoloji gerekse küreselleşme ile beraber gelişim gösteren birtakım unsurlara ayak uydurmasının, diğer bir ifade ile sosyal medyanın gündelik hayatın vazgeçilmez bir parçası haline gelmiş olmasının etkili olduğu düşünülebilir. 
Ayhan DEVER ve Mehmet KOCA, “Beden Eğitimi ve Spor Yüksek Okulu Öğrencilerinin Sosyal Medya Kullanımına Yönelik Düzeylerinin Değerlendirilmesi: Ordu Üniversitesi Örneği”, Mavi Atlas, 5(2)/2017: 383-401.

Araştırmadan elde edilen bir diğer bulgu ise araştırmaya katılan bireylerin sosyal medyayı kullanma durumlarının, ailelerinin ekonomik gelir durumuna göre farklılık göstermediğidir. Bu sonuca göre, bireylerin sosyal medyayı kullanma durumları ile gelirleri arasında bir ilişki bulunmamaktadır. Çünkü sosyal medyada oluşturulan sanal kimlikler ile birey kendi gelir konusuna herhangi bir vurgu yapmamakta veya kendisini çok zengin olarak da ifade edebilmektedir. Diğer bir ifade ile sosyal medya kullanımında, ailenin içerisinde bulunduğu sınıf / tabaka etkili olmamaktadır. Ayrıca sosyal medya kullanma durumunun, araştırmaya katılan bireylerin milli sporcu olma durumuna göre farklılık göstermediği tespit edilmiştir.

Sosyal medyayı kullanma durumunun ailenin yaşadığı yere göre farklılığ incelendiğinde, ilgi çekme alt ölçeği bakımından anlamlı farklılık tespit edilmiştir. Özellikle ilçelerde yaşayan bireyler, sosyal medyayı daha ziyade ilgi çekme aracı olarak kullanmaktadırlar. Bu sonuç üzerinde ise, özellikle ilçelerde yaşayan bireylerin, diğer yerleşim yerlerinde yaşayan bireylere nazaran kendilerini daha net ifade etme çabasının etkili olduğu düşünülebilir. 
Ayhan DEVER ve Mehmet KOCA, "Beden Eğitimi ve Spor Yüksek Okulu Öğrencilerinin Sosyal Medya Kullanımına Yönelik Düzeylerinin Değerlendirilmesi: Ordu Üniversitesi Örneği”, Mavi Atlas, 5(2)/2017: 383-401.

\section{KAYNAKÇA}

AKOVA, İsmet (2012). “Turizm Coğrafyası ve Planlama”, Turizm Coğrafyası, ed. Semra Günay, ss. 2-36, Eskişehir: Anadolu Üniversitesi Yayınları.

ALPER, Ayfer (2012). Sosyal A ğlar, (Ed. A. Alper), Ankara: Pelikan Yayınılık.

BAYRAKTUTAN G, ve diğerleri (2012). "Sosyal Medyada 2011 Genel Seçimleri: Nicel-Nitel Arayüzey İncelemesi”, Selçuk İletişim Dergisi, 7 (3), 15-16.

BEZCI, Büyamin (2015). "Kamusallığı Akıcı Kılan Ama Temsiliyeti Buharlaştıran Bir Sorun Olarak Sosyal Medya", (Ed. Oğuzhan, Ö.), Iletişimde Sosyal Medya Sosyal Medyada Etkileşim, İstanbul: Kalkedon Yayınları.

DELLALOĞLU, F. Besim (2015). "Mesafeli Yakınlı: Fecebook ve Twitter Çağının Yeni Toplumsallığı”, (Ed. Oğuzhan, Ö.), Illetişimde Sosyal Medya Sosyal Medyada Etkileşim, İstanbul: Kalkedon Yayınları.

DEMIR, Müge (2015). "Kullanımlar ve Doyumlar Kuramı Bağlamında Sosyal Medya Kullanımı: Beykent Üniversitesi Örneği”, (Ed. Oğuzhan, Ö.), İletişimde Sosyal Medya Sosyal Medyada Etkileşim, İstanbul: Kalkedon Yayınları.

FUCHS, Christian (2014). Sosyal Medya: Eleştirel Bir Giriş, (Çev. Saraçoğlu, D. Ve Kalayc1, I.), Ankara: NotaBene Yayınları.

GIDDENS, Anthony ve SUTTON W. Philip (2016). Sosyoloji, Haz: A. N. Durakbaşa - F. K. Şenel - S. Tüfekçioğlu, Kırmızı Yayınları: İstanbul.

KIRIK, A.M. (2013), “Gelişen Web Teknolojileri ve Gelişen sosyal Medya Bağımlılığı”, Sosyal Medya Araştırmaları 1, (Ed. Büyükaslan, A. Ve Kırık, A. M.), Konya: Çizgi Kitabevi.

OSKAY, Ünsal (2005). Illetişimin ABC'si, İstanbul: Der Yayınları.

OTRAR, M. - ARGIN, F. S. (2016). Sosyal Medya Kullanımına Yönelik Tutum Ölçeğinin Geçerlilik ve Güvenirlilik Çalışması, III. International Eurasian Educational Research Congress, Muğla.

TIRYAKI, Salih (2015). Sosyal Medya ve Facebook Bağımlılı̆̆l, Konya: Literatürk Akademia.

TUMASJAN, Andranik ve Vd. (2010). "Predicting Elections with Twitter: What 140 Characters Reveal about Political Sentiment", Proceedings of the Fourth International AAAI Conference on Weblogs and Social Media, (Erişim Tarihi: 19.05.2017)

YENIÇIKTI, T. Nagihan (2016). "Halkla İlişkiler Aracı Olarak Instagram: Sosyal Medya Kullanan 50 Şirket Üzerine Bir Araştırma”, Selçuk İletişim Dergisi, 2016, 9 (2).

https://www.slideshare.net/wearesocialsg/2016-digital-yearbook. 